\title{
Correction to: Predictability of success and open conjunctival revision rates in the subsequent eye after XEN45 Gel Stent implantation according to lens status
}

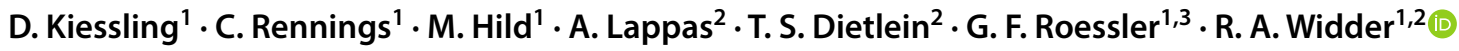

Published online: 3 March 2022

(c) The Author(s) 2022

\section{Correction to: Graefe's Archive for Clinical and Experimental Ophthalmology https://doi.org/10.1007/s00417-022-05569-x}

In the published version of this article, the author names presentation is incorrect.

The correct presentation is provided below.

D Kiessling

C Rennings

M Hild

A Lappas

TS Dietlein

GF Roessler

RA Widder

This is being corrected in this publication.
Open Access This article is licensed under a Creative Commons Attribution 4.0 International License, which permits use, sharing, adaptation, distribution and reproduction in any medium or format, as long as you give appropriate credit to the original author(s) and the source, provide a link to the Creative Commons licence, and indicate if changes were made. The images or other third party material in this article are included in the article's Creative Commons licence, unless indicated otherwise in a credit line to the material. If material is not included in the article's Creative Commons licence and your intended use is not permitted by statutory regulation or exceeds the permitted use, you will need to obtain permission directly from the copyright holder. To view a copy of this licence, visit http://creativecommons.org/licenses/by/4.0/.

Publisher's note Springer Nature remains neutral with regard to jurisdictional claims in published maps and institutional affiliations.

The original article can be found online at https://doi.org/10.1007/ s00417-022-05569-x.

R. A. Widder

r.widder@martinus-duesseldorf.de

1 Department of Ophthalmology, St. Martinus-Krankenhaus Düsseldorf, Gladbacher Str. 26, 40219 Düsseldorf, Germany

2 Department of Ophthalmology, University Hospital of Cologne, Cologne, Germany

3 Department of Ophthalmology, RWTH Aachen, Aachen, Germany 